\title{
BOBİ FRS'yi Uygulayan İşletmelerin Maddi Duran Varlıklar İçin Maliyet Modeli ve Yeniden Değerleme Modeline Göre Yapacağı Muhasebe
}

\section{Kayitları}

\author{
Nagihan ALBENi $1^{*}$
}

Geliş Tarihi/Received: 20.09 .2021

Kabul Tarihi/Accepted: 18.10.2021

Araştırma Makalesi/Research Article

\section{ÖZET}

Bu çalışmada BOBİ FRS Bölüm 12 Maddi Duran Varlıklar ele alınmıştır. Bir örnek yardımıyla, varlık olarak muhasebeleştirilen bir maddi duran varlık için sonradan uygulanacak maliyet modeli ve yeniden değerleme modeline göre muhasebe kayıtlarının nasıl yapılacağının gösterilmesi amaçlanmıştır. Muhasebe kayıtları yapılırken Kamu Gözetimi Muhasebe ve Denetim Standartları Kurumu tarafindan yayımlanan Finansal Raporlama Standartlarına Uygun Örnek Hesap Planı kullanılmıştır. Ayrıca uygulanan maliyet modeli ve yeniden değerleme modeli karşılaştırılmış, farklılıklar belirtilmiş ve bu farklılıkların nedenleri açıklanmaya çalışılmıştır.

Anahtar Kelimeler: Büyük ve Orta Boy İşletmeler için Finansal Raporlama Standard1, Maddi Duran Varlıklar, Maliyet Modeli, Yeniden Değerleme Modeli

\section{Accounting Records to Be Made by Businesses Applying FRS for LMEs According to the Cost Model and Revaluation Model for Tangible Fixed}

Assets

\section{ABSTRACT}

In this study, FRS for LMEs Section 12 Tangible Fixed Assets Standard has been discussed. With the help of an example, it is aimed to show how the records will be made

\footnotetext{
${ }^{1}$ Öğr. Gör. Dr., Burdur Mehmet Akif Ersoy Üniversitesi, Zeliha Tolunay Uygulamalı Teknoloji ve İşletmecilik Yüksekokulu, Gümrük İşletme Bölümü, Orcid No: 0000-0001-7785-6665

* Sorumlu yazar/Corresponding author

E-mail/e-ileti: nagihanalbeni@gmail.com
} 


\section{Albeni, N.}

according to the cost model and revaluation model to be applied later for a tangible asset accounted as an asset. While making the accounting records, the Sample Chart of Accounts in Accordance with the Financial Reporting Standards published by the Public Oversight Accounting and Audit Standards Authority was used. In addition, the applied cost model and revaluation model were compared, the differences were stated and the reasons for these differences are tried to be explained.

Key Words: Financial Reporting Standard for Large and Medium Sized Enterprises, Tangible Fixed Assets, Cost Model, Revaluation Model.

\section{GíRiş}

Büyük ve Orta Boy İşletmeler için Finansal Raporlama Standardı (BOBİ FRS), Türkiye Finansal Raporlama Standartları (TFRS)' yi uygulamayan ancak Kamu Gözetimi Muhasebe ve Denetim Standartları Kurumu (KGK) tarafından bağımsız denetime tabi olan işletmeler için gerçeğe uygun ve karşılaştırılabilir finansal tabloların düzenlenmesini sağlamak amacıyla 29/07/2017'de yayımlanmış ve 01/01/2018'de yürürlüğe girmiştir.

Bu çalışmada BOBİ FRS Bölüm 12'ye göre bir maddi duran varlık ilk kayda alındıktan sonra işletmenin seçeceği maliyet modeli ve yeniden değerleme modeline göre muhasebe kayıtlarının Kamu Gözetimi Muhasebe ve Denetim Standartları Kurumu tarafından yayımlanan Finansal Raporlama Standartlarına Uygun Örnek Hesap Planına göre nasıl yapılması gerektiği gösterilmeye ve modeller arası karşılaştırma yapılarak aradaki farklılıkların nedenleri açıklanmaya çalışılmıştır.

\section{LITTERATÜR ÇALIȘMASI}

Maddi duran varlıkların muhasebeleştirilmesi ile ilgili yapılan literatür taramasında, yazarların konuyu çoğunlukla TMS açısından ele aldıkları tespit edilmiş, BOBİ FRS kapsamında ise çalışmaların yetersiz olduğu sonucuna ulaşılmıştır. Yapılan literatür taraması sonucunda ulaşılan çalışmalar aşağıda özetlenmiş ve değerlendirilmiştir.

Yelgen ve Uyar (2018), çalışmalarında maddi duran varlıklara ilişkin ilk kayda alma, vade farkları ve borçlanma maliyetleri, sonraki ölçüm, amortisman ve bilanço dışı bırakma konuları BOBİ FRS açısından değerlendirmişlerdir. Çalışma sonucunda maddi duran varlıkların sonraki ölçüm, borçlanma maliyetleri ve amortisman konularında TFRS ile uyumlu olduğu, vade farklarını uygulama noktasında TFRS'den farklı olduğunu tespit edilmiştir.

Çanakçıŏlu (2018), çalışmasında BOBİ FRS, tam set TFRS ve Vergi Usul Kanunu (VUK)'na göre maddi duran varlıkların ilk ölçümü, aktifleştirildikten sonraki ölçümlemede 
kullanılan maliyet ve yeniden değerleme modelleri ile varlıklardaki değer düşüklüğü konularını ele almıştır. Çalışmada maddi duran varlıkların ilk ölçüm sırasında VUK ve standartlar arasında çok büyük bir faklılık olmamasına karşın, muhasebeleştirme sonrası ölçüm sırasında VUK'da olmayan ve standartlarda gerçeğe uygunluk ilkesi adına yapılan çeşitli uygulamaların mevcut olduğu sonucuna ulaşılmıştır.

Yücel vd. (2018), çalışmalarında Türkiye'deki güncel muhasebe mevzuatı açısından maddi duran varlıkların değerlemesine ilişkin hükümlerin karşılaştırılmasını yapmışlar. Çalışma sonunda da maddi duran varlıkların özellikle dönem sonu işlemlerinde TMS/TFRS ve BOBİ FRS'de ilke bazlı uygulamaların esas alındığını; ilk muhasebeleştirme ve elden çıkarma konusunda TMS 16'da ilke bazlılık devam ettirilirken BOBİ FRS'de uygulama kolaylığ1 açısından "1 yıl” süre tayini yapıldığını; Muhasebe Sistemi Uygulama Genel Tebliği (MSUGT)'lerinde ise maddi duran varlıklar ile ilgili detaylı düzenlemenin yer almadığı, vergi amaçlı uygulamaların ağır bastığını tespit etmişlerdir.

Tunçez (2020), çalışmasında maddi duran varlıkların muhasebeleştirilmesine ilişkin işlemleri TMS 16 ve BOBİ FRS Bölüm 12 kapsamında karşılaştırmıştır. Çalışmada ilk kayda alma, değerleme, amortisman ve mali tablo dışı bırakılma konuları ele alınmış, ilk kayda alma ve amortisman ile ilgili örnekler sunulmuştur. Çalışma sonucunda TMS 16 ve BOBİ FRS 12'nin birbirleriyle uyumlu olmakla beraber bazı farkl1lıkların da söz konusu olduğu belirtilmiştir.

Maddi duran varlıkların BOBİ FRS'ye göre değerlendirilmesi ile ilgili çalışmalara bakıldığında bu konu üzerinde yapılan çalışmaların yetersiz olduğu söylenebilir. Şuana kadar yapılan çalışmalara bakıldığında maddi duran varlıklar Türkiye Muhasebe Standartları (TMS), BOBİ FRS ve Vergi Usul Kanunu (VUK)'na göre karşılaştırılmış, benzerlik ve farklılıklar belirtilmeye çalışılmıştır. Bu çalışmayı diğer çalışmalardan ayıran özellik ise konunun bütünlügü bozulmadan tek bir örnek yardımıyla BOBİ FRS Bölüm 12'ye göre maddi duran varlığın ilk kayda alınması, sonraki ölçümünde kullanılan maliyet modeli ve yeniden değerleme modeline göre değerlendirilmesi, amortisman ayrılması ve finansal tablo dışı bırakılması işlemlerinde işletmenin yapacağı muhasebe kayıtlarının Kamu Gözetimi Muhasebe ve Denetim Standartları Kurumu tarafindan yayımlanan Finansal Raporlama Standartlarına Uygun Örnek Hesap Planı kullanılarak gösterilmeye çalışılmış olması ve sonraki ölçümde modeller arası karşılaştırma yapılarak aradaki farklılıkların nedenlerinin açıklanmaya çalışılmış olmasıdır. 


\section{Albeni, N.}

\section{BOBİ FRS BÖLÜM 12 MADDİ DURAN VARLIKLAR VE DEĞERLEME}

Bağımsız denetime tabi olup Tam Set TMS/TFRS uygulamayan işletmeler için uygulanacak finansal raporlama standardı konusunda KGK, 2014 yılında çalışmalara başlamış ve çalışma nihai hale gelinceye kadar Yerel Finansal Raporlama Çerçevesi olarak isimlendirilmiştir. Gerçeğe ve ihtiyaca uygun, karşılaştırılabilir finansal bilgi sunumunu sağlayacak yerel bir finansal raporlama standardının çıkarılması çalışmaları, 2017 yılında sonuçlanmış olup standart, 29 Temmuz 2017 tarihli ve 30138 sayılı Mükerrer Resmi Gazetede Büyük ve Orta Boy İşletmeler İçin Finansal Raporlama Standardı adı ile yayınlanmıştır (Ataman \& Cavlak, 2017). Güncellenen BOBİ FRS 2021 Sürümü ise 30/03/2021'de Resmi Gazete'de yayımlanmıştır.

$\mathrm{Bu}$ uygulama ile TMS ve TFRS ve yorumlarını zorunlu olarak uygulayan kuruluşlar dışında kalan aktif büyüklügü, satış hasılatı ve çalışan sayısının en az ikisini birlikte sağlayan firmaların raporlamalarını BOBİ FRS'ye göre yapma zorunluluğu getirilmiştir. Bu zorunlulukla birlikte BOBİ FRS uygulamasının ne şekilde yapılacak olduğunun bilinmesi, firmaların hata ve yanlış yapma olasılıklarını düşürecektir (Durmuş \& Kutlu, 2020).

Muhasebe standartlarının öngördüğü finansal tabloların kapsamı ile Maliye Bakanlığı tarafindan yayınlanan Tekdüzen Hesap Planı tam uyumlu olmadığından, TFRS ve BOBİ FRS'ye uyumlu finansal tablolar muhasebe kayıtlarından doğrudan elde edilememektedir. Bu eksikliği gidermek için muhasebe standartlarıyla uyumlu hesap planına ihtiyaç duyulmaktadır (Lazol, 2020).

$\mathrm{Bu}$ ihtiyacı karşılamak amacıyla Kamu Gözetimi Muhasebe ve Denetim Standartları Kurumu tarafından yayımlanan Finansal Raporlama Standartlarına Uygun Örnek Hesap Planı yayımlanmıştır.

Yayımlanan Örnek Hesap Planı; "İ̧̧letmelerin finansal durumu ve faaliyet sonuçlarını sağlıklı ve güvenilir bir biçimde geçerli finansal raporlama çerçevesine göre izlemesine ve finansal tablolarını geçerli finansal raporlama çerçevesine uygun olarak hazırlamasına imkân veren bir muhasebe sistemi oluşturabilmesi amaciyla örnek olarak oluşturulmuştur. Bu hesap planı ayrıca sunulan finansal bilgilerin gerçeğe ve ihtiyaca uygun, anlaşılabilir, doğrulanabilir ve karşılaştırılabilir olma niteliklerinin arttırılmasını, işletmeler tarafından kullanılan hesaplarda yeknesaklığın sağlanmasını ve işletmelerde denetimin kolaylaştırılmasını amaçlamaktadır” (Kamu Gözetimi Kurumu (KGK), 2021).

İşletmelerin faaliyet alanlarına göre önem derecesi farklılık gösterse de, maddi duran varlıklar genel itibarıyla bir işletmenin önemli ve etkili kalemleri arasında bulunmaktadır. 
Özellikle sanayi işletmeleri için duran varlık yatırımı, ticari ya da hizmet sektöründe yer alan işletmelere göre daha önemli bir süreçtir (Güleç, 2018).

BOBİ FRS Bölüm 12'de, "Maddi duran varlıklara ilişkin muhasebe ilkeleri düzenlenmektedir. Bu kapsamda maddi duran varlıkların ilk kayda alınması, defter değerlerinin belirlenmesi ve bu varlıklarla ilgili amortisman ve değer düşüklüğü konuları ele alınmaktadır” (BOBİ FRS, paragraf 12.1).

Bölüm 12'ye göre "Maddi duran varlıklar, mal veya hizmet üretiminde veya arzında kullanılmak, başkalarına kiraya verilmek veya idari amaçlar çerçevesinde kullanılmak üzere elde tutulan ve birden fazla dönemde kullanımı öngörülen fiziki kalemlerdir” (BOBİ FRS, paragraf 12.2).

"Maddi duran varlıklar, ilk kayda almada maliyet bedeliyle ölçülür” (BOBİ FRS, paragraf 12.6).

"Satın alınan maddi duran varlığın maliyet bedeli; ticari iskontolar ve indirimler çıkarıldıktan sonraki satın alma fiyatından, satın alma işlemine bağlı olarak yapılan giderlerden ve varlığın yönetim tarafından amaçlanan koşullarda kullanılabilmesini sağlayacak konuma ve duruma getirilmesiyle doğrudan ilişkilendirilebilen maliyetlerden oluşur" (BOBİ FRS, paragraf 12.7).

"İşletme tarafından inşa ve imal edilen varlıkların maliyetleri de satın alma yoluyla edinilen varlıklarla aynı ilkelere göre belirlenir” (BOBİ FRS, paragraf 12.11).

Bölüm 12'ye göre “Maddi duran varlıklar, sonraki ölçümlerinde birikmiş amortisman ve birikmiş değer düşüklüğü zararları indirilmek suretiyle maliyeti üzerinden veya yeniden değerlenmiş tutarı üzerinden değerlenir. Maddi duran varlıkla ilgili yapılan olağan bakım ve onarım giderleri varlığın maliyetine dâhil edilmez” (BOBİ FRS, paragraf 12.15).

Maddi duran varlığın sonraki ölçümünde kullanılabilecek modeller aşağıda gösterildiği gibidir (KGK, BOBİ FRS Modül 12):

- $\quad$ Maliyet Modeli: Maliyet-Birikmiş Amortisman-Birikmiş Değer Düşüklüğü

- $\quad$ Yeniden Değerleme Modeli: Yeniden Değerleme Tarihindeki Gerçeğe Uygun Değer-Müteakip Birikmiş Amortisman-Müteakip Birikmiş Değer Düşüklüğü Zararı

“İlk kayda almadan sonra bir maddi duran varlık yeniden değerlenmiş tutarı üzerinden ölçüldüğünde ölçüme esas alınacak değer, yeniden değerlemenin yapıldığı tarihteki gerçeğe uygun değeridir. $\mathrm{Bu}$ tarihten sonra varlığın yeniden değerlenmiş tutarı; varlığın yeniden değerlendiği tarihteki gerçeğe uygun değerinden, yeniden değerlemenin yapıldı̆̆ sonraki birikmiş amortisman tutarı ve birikmiş değer düşüklüğü zararı indirilerek hesaplanır. Yeniden değerleme, ilgili varlığın defter değerinin raporlama dönemi sonundaki gerçeğe uygun 


\section{Albeni, N.}

değerinden önemli ölçüde farklı olmamasını sağlayacak şekilde düzenli aralıklarla yapılır” (BOBİ FRS, paragraf 12.16).

BOBİ FRS Bölüm 12'ye göre; “Bir maddi duran varlık kaleminin yeniden değerlemesinin yapılması durumunda bu varlığın yer aldığı maddi duran varlık sınıfındaki diğer varlıklar da yeniden değerlemeye tâbi tutulur” (BOBİ FRS, paragraf 12.18).

"Bir maddi duran varlık yeniden değerlemeye tabi tutulduğunda, varlığın defter değeri yeniden değerlenmiş tutara göre düzeltilirken aşağıda yer verilen yöntemlerden biri kullanılabilir" (KGK, BOBİ FRS Modül 12):

- Brüt Yöntem:

"Varlığın brüt değeri, varlığın defter değerinin yeniden değerlemesiyle tutarlı bir şekilde düzeltilir. Bu durumda, yeniden değerleme tarihindeki birikmiş amortisman, varlığın brüt değeri ile varlığın birikmiş değer düşüklüğü zararlarının dikkate alınmasından sonraki defter değeri arasındaki fark kadar düzeltilir, yani varlığın defter değeri yeniden değerlenmiş tutara getirilerek, defter değerindeki oransal değişim kadar birikmiş amortisman ve varlığın brüt değeri düzeltilir ya da" (KGK, BOBİ FRS Modül 12)

- $\quad$ Net Yöntem:

"Birikmiş amortisman varlığın brüt değeri ile netleştirilir ve varlığın brüt değeri defter değerine eşitlenmiş olur. Bu kapsamda, yapılan yeniden değerleme sonucunda varlı̆̆ın defter değeri ile yeniden değerlenmiş tutarı arasındaki fark "Yeniden Değerleme Yedeği"ne kaydedilir ve karşılığında "Birikmiş Amortismanlar" kalemi sıfıra indirilerek varlığın brüt değeri yeniden değerlenmiş tutara getirilir”" (KGK, BOBİ FRS Modül 12).

"Bir maddi duran varlığın defter değerinin yeniden değerleme sonucunda artması durumunda, bu artış Finansal Durum Tablosunda özkaynaklarda "Yeniden Değerleme Yedeği" kaleminde gösterilir. Ancak, bu artış, aynı varlığın daha önce kâr veya zarara yansıtılan yeniden değerleme değer azalışını tersine çevirdiği ölçüde kâr veya zararda gösterilir. Bir maddi duran varlığın defter değerinin yeniden değerleme sonucunda azalması durumunda, bu azalışın aynı varlık için yeniden değerleme yedeğinde yer alan tutar kadarlık kısmı yeniden değerleme yedeğinden indirilir. Ancak yeniden değerleme azalışının yeniden değerleme yedeğinde yer alan tutardan yükssek olması durumunda aradaki fark Kâr veya Zarar Tablosunda ilgili varlığın kullanıldığı işletme fonksiyonuna ilişkin giderlerin yansıtıldığı kalemde kâr veya zarara yansitılır” (BOBİ FRS, paragraf 12.19).

"Bir maddi duran varlığın ilk kez yeniden değerlemeye tabi tutulması sonucunda defter değerinde meydana gelen artış Finansal Durum Tablosunda özkaynaklarda "Yeniden Değerleme Yedeği”" kaleminde; azalış ise Kâr veya Zarar Tablosunda gösterilmektedir. Diğer 
taraftan, bir maddi duran varlığın ilk kez yeniden değerlemeye tabi tutulması durumunda kâr veya zarara yansıtılan değer azalışı, sonraki dönemlerde yapılan yeniden değerleme artışları ile tersine çevrilir. Bir başka ifadeyle, sonraki dönemlerde yapılan yeniden değerlemenin değer düşüklüğü zararına tekabül eden kısmı kâr veya zarara yansıtılırken, bu zararı aşan kısım ise Finansal Durum Tablosunda özkaynaklarda "Yeniden Değerleme Yedeği” kalemine yansıtılır. Bununla birlikte, ilk kez yeniden değerlemeye tabi tutulan ve "Yeniden Değerleme Yedeği" kalemine yansıtılan bir maddi duran varlığın değerindeki artışın sonraki dönemlerde azalması durumunda, söz konusu azalış 12.19 paragrafında belirtildiği azalışının, "Yeniden Değerleme Yedeği” kaleminden indirilir. Ancak söz konusu değer azalışının, "Yeniden Değerleme Yedeği” kalemindeki tutarı aşması durumunda, aşan kısım zarar olarak Kâr veya Zarar Tablosunda gösterilir"' (KGK, BOBİ FRS Modül 12).

BOBİ FRS Bölüm 12'ye göre amortisman ile ilgili paragrafları aşağıdaki gibidir:

"Maddi duran varlıklar için amortisman ayrılması zorunludur" (BOBİ FRS, paragraf 12.21). Amortismana tâbi tutar, maddi duran varlığın maliyet bedelinden ya da yeniden değerleme sonrası bulunan tutardan kalıntı değerin indirilmesiyle belirlenir" (BOBİ FRS, paragraf 12.24). Maddi duran varlığın amortismana tâbi tutarı faydalı ömrü süresince sistematik bir şekilde dağıtılır. Faydalı ömür, bir varlığın işletme tarafından beklenen kullanım süresini ya da işletme tarafından ilgili varlıktan elde edilmesi beklenen üretim veya kullanım miktarını ifade eder. Faydalı ömür işletme tarafından gerçekçi tahminlere dayanılarak belirlenir" (BOBİ FRS, paragraf 12.25).

“Amortisman işlemine, varlık yönetim tarafından amaçlanan kullanıma hazır hale geldiği tarih itibarıyla başlanır ve varlığın finansal tablo dışı bırakılmasıyla son verilir. Dolayısıyla dönem içerisinde kullanıma alınan amortismana tâbi tüm varlıklar için kıst amortisman hesaplanır (BOBİ FRS, paragraf 12.26). Amortisman ayırma işlemine, varlık atıl bırakıldığında ya da kullanımdan kaldırıldığında da devam edilir. Ancak, üretim miktarı yöntemine göre amortisman uygulanırken, amortisman gideri, üretim veya kullanım olmadığ 1 zamanlarda sıfır olabilir" (BOBİ FRS, paragraf 12.30).

"Kalıntı değer, bir varlık tahmin edilen faydalı ömrünün sonundaki durum ve yaşına ulaştığında elden çıkarılması sonucu elde edilmesi beklenen tutardan, elden çıkarmanın tahmini maliyetleri düşülerek ulaşılan tahmini tutardır. Kalıntı değer, önemsiz olması durumda amortismana tâbi tutarın belirlenmesinde dikkate alınmaz” (BOBİ FRS, paragraf 12.27).

“Amortisman yöntemi, varlığın gelecekteki ekonomik faydasının işletme tarafından öngörülen tüketim şeklini yansıtacak şekilde belirlenir. Maddi duran varlıktan elde edilecek 


\section{Albeni, N.}

gelecekteki ekonomik faydaların beklenen tüketim biçiminde bir değişiklik olmadıkça, seçilen yöntem dönemler itibarıyla tutarlı olarak uygulanır” (BOBİ FRS, paragraf 12.28).

“Amortisman uygulaması için çeşitli yöntemler kullanılabilir. Doğrusal yöntem, azalan bakiyeler yöntemi ve üretim miktarı yöntemleri bu yöntemlere örnek olarak verilebilir. Doğrusal yöntemde, varlığın kalıntı değeri değişmediği sürece, amortisman gideri faydalı ömrü boyunca sabittir. Azalan bakiyeler yönteminde, amortisman gideri faydalı ömrü boyunca azalır. Üretim miktarı yönteminde beklenen kullanım ya da üretim miktarı üzerinden amortisman ayrılır” (BOBİ FRS, paragraf 12.29).

"Döneme ilişkin amortisman giderleri, başka bir varlığın defter değerine dâhil edilmediği sürece, kâr veya zarara yansıtılır. Kâr veya zarara yansitılan amortisman giderleri Kâr veya Zarar Tablosunda ilgili varlığın kullanıldığı işletme fonksiyonlarına ilişkin giderlerin raporlandığı kalemlerde gösterilir” (BOBİ FRS, paragraf 12.32).

“Her bir raporlama dönemi sonunda maddi duran varlık kalemlerinde değer düşüklüğü olup olmadığının ve varsa değer düşüklüğü zararının nasıl ölçülüp muhasebeleştirileceğinin belirlenmesi için "Varlıklarda Değer Düşüklüğü" bölümünde belirtilen hükümler uygulanır" (BOBİ FRS, paragraf 12.33).

BOBİ FRS Bölüm 18 Varlıklarda Değer Düşüklüğü’nde yer alan ilgili paragraflar aşağıdaki gibidir:

"Varlıkların geri kazanılabilir tutarından daha yüksek bir değerle finansal tablolarda yer almamasını sağlamak amacıyla, değer düşüklüğüne ilişkin muhasebe ilkeleri düzenlenmektedir. Bu kapsamda, bu bölümde varlıklara ilişkin değer düşüklüğü zararlarının belirlenmesi ve hesaplanması ile bu zararların iptal edilmesi konuları ele alınmaktadır" (BOBİ FRS, paragraf 18.1).

“Her raporlama dönemi sonunda varlığın değer düşüklüğüne uğradığına ilişkin bir göstergenin mevcut olup olmadığı değerlendirilir. Bu tür bir göstergenin mevcut olması durumunda ilgili varlığın geri kazanılabilir tutarı belirlenir. Belirsiz faydalı ömre sahip maddi olmayan duran varlıklar da dâhil olmak üzere varlığın değer düşüklüğüne uğradığına ilişkin herhangi bir göstergenin bulunmadığı durumlarda geri kazanılabilir tutarın belirlenmesine gerek yoktur” (BOBİ FRS, paragraf 18.4).

“Geri kazanabilir tutar, varlığın (veya nakit yaratan birimin) satış maliyetleri düşülmüş gerçeğe uygun değeri ile kullanım değerinden yüksek olanıdır. Varlıklar, geri kazanılabilir tutarından daha yüksek bir tutarla Finansal Durum Tablosunda izlenemez. Bir varlığın defter değerinin geri kazanılabilir tutarından büyük olması durumunda değer düşüklüğü zararı oluşur” (BOBİ FRS, paragraf 18.3). 
“Satış maliyetleri düşülmüş gerçeğe uygun değer, bir varlığın, bilgili ve istekli taraflar arasında karşılıklı pazarlık ortamında piyasa şartları çerçevesindeki satış tutarından, elden çıkarma maliyetleri indirildikten sonra elde edilebilecek tutardır” (BOBİ FRS, paragraf 18.12). "Satış maliyetleri düşülmüş gerçeğe uygun değerin hesaplanmasında, gerçeğe uygun değerden indirilebilecek satış maliyetlerine yasal olarak ödenmesi gereken işlem vergileri ve benzeri diğer ödemeler, varlığı taşıma maliyetleri, varlığın tâbi olduğu bir kısıtlamanın kaldırılması amacıyla katlanılan maliyetler ve varlığ 1 satışa hazır hale getirmek için katlanılan ilave maliyetler örnek olarak gösterilebilir" (BOBİ FRS, paragraf 18.14). "Kullanım değeri, bir varlıktan elde edilmesi beklenen gelecekteki nakit akışlarının bugünkü değeridir” (BOBİ FRS, paragraf 18.15).

"Maddi duran varlığın geri kazanılabilir tutarı kullanım değeri ile satış maliyetleri düşülmüş gerçeğe uygun değerinden yüksek olanıdır” (KGK, BOBİ FRS Modül 12).

İşletme belirlediği geri kazanılabilir tutarı maddi duran varlığın defter değeri ile karşılaştırır. Maddi duran varlığın defter değerinin geri kazanılabilir tutarı aşması durumunda, aşan bu tutar maddi duran varlığın değer düşüklüğü zararını teşkil etmektedir (KGK, BOBİ FRS Modül 12).

"Bireysel olarak değer düşüklüğü testine tâbi tutulan ve maliyet bedeliyle ölçülen varlıklara ilişkin değer düşüklüğü zararları kâr veya zarara yansıtılır. Ancak yeniden değerlenmiş tutarı üzerinden ölçülen maddi duran varlıklara ilişkin değer düşüklüğü zararları “Maddi Duran Varlıklar” bölümüne göre yeniden değerleme değer azalışı olarak dikkate alınır. Kâr veya zarara yansıtılan değer düşüklüğü zararları Kâr veya Zarar Tablosunda varlığın kullanıldı̆̆ı işletme fonksiyonuna ilişkin giderlerin yansıtıldı ̆̆ kalemde gösterilir. Örneğin, pazarlama bölümüyle ilgili olarak kullanılan varlığa ilişkin değer düşüklüğü zararı "Pazarlama Giderleri” kaleminde, üretim bölümüyle ilgili kullanılan varlıklara ilişkin değer düşüklüğü zararı ise "Satışların Maliyeti”" kaleminde gösterilir" (BOBİ FRS, paragraf 18.27).

“Değer düşüklüğü zararının muhasebeleştirilmesinden sonra amortisman veya itfa payı gelecekteki dönemlerde varlığın yeni defter değeri esas alınarak hesaplanır” (BOBİ FRS, paragraf 18.31).

"Her raporlama dönemi sonunda, önceki raporlama dönemlerinde kaydedilen değer düşüklüğü zararının ortadan kalktığına ya da azaldığına ilişkin bir gösterge bulunup bulunmadığı değerlendirilir” (BOBİ FRS, paragraf 18.32).

"Bu tür bir göstergenin bulunması durumunda, ilgili varlığın ya da nakit yaratan birimin geri kazanılabilir tutarı hesaplanarak daha önce kaydedilen değer düşüklügü zararının bir 


\section{Albeni, N.}

kısmının veya tamamının iptal edilip edilmemesi gerektiği belirlenir” (BOBİ FRS, paragraf 18.32).

"Varlığın geri kazanılabilir tutarının defter değerini aşması durumunda ilgili varlığa ilişkin değer düşüklüğü zararının tamamı ya da bir kısmı iptal edilir. Değer düşüklügü zararının iptal edilecek kısmı, ilgili varlığa ilişkin önceki raporlama dönemlerinde değer düşüklüğü zararı kayda alınmamış olsaydı varlığın ulaşacağı (amortisman veya itfa payı çıkarılmış olarak) defter değeri esas alınarak belirlenir. Değer düşüklüğü zararının iptalinden sonra varlığın yeni defter değeri bu değeri aşamaz" (BOBİ FRS, paragraf 18.34).

“İptal edilecek değer düşüklügü zararı; bireysel olarak değer düşüklüğü testine tâbi tutulan ve maliyet bedeli ile ölçülen varlıklarda kâr veya zarara yansıtılarak Kâr veya Zarar Tablosunun ilgili kaleminde gösterilirken, yeniden değerlenmiş tutarı üzerinden ölçülen maddi duran varlıklarda "Maddi Duran Varlıklar" bölümüne göre yeniden değerleme değer artış1 olarak dikkate alınır" (BOBİ FRS, paragraf 18.35).

“Değer düşüklüğü zararının iptal edilmesinden sonra amortisman veya itfa payı sonraki dönemlerde varlığın yeni defter değeri esas alınarak hesaplanır” (BOBİ FRS, paragraf 18.40).

"Bir maddi duran varlık kalemi, elden çıkarıldığında veya varlıktan gelecekte herhangi bir ekonomik fayda beklenmediği durumda finansal tablo dışı bırakılır” (BOBİ FRS, paragraf 12.35).

"Bir maddi duran varlık kaleminin finansal tablo dışı bırakılmasından doğan kazanç ya da kayıp kâr veya zarara yansıtılır” (BOBİ FRS, paragraf 12.36).

"Bir maddi duran varlık finansal tablo dışı bırakıldığında bu varlığa ilişkin olarak yeniden değerleme yedeğinde yer alan birikmiş tutar "Geçmiş Yıllar Kârları/Zararları" kalemine aktarılır" (BOBİ FRS, paragraf 12.20).

Bir maddi duran varlık kalemi ilk kayda maliyet bedeliyle alındıktan sonraki ölçüme ilişkin işletme tarafından uygulanacak yöntemlerin işleyişi aşağıdaki şekilde anlatıldığı gibidir. 


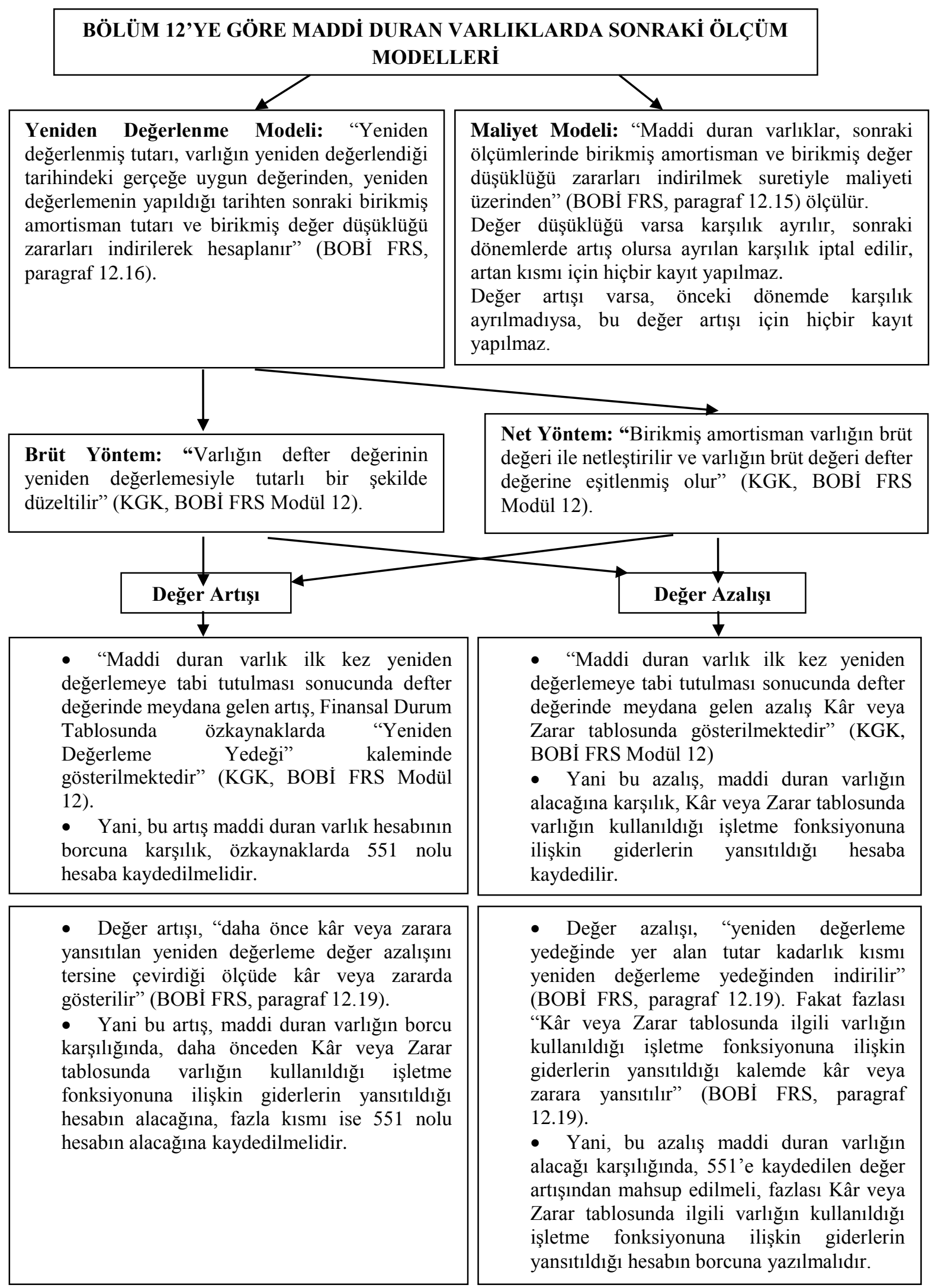

Şekil 1. İlk kayda alınan maddi duran varlık kalemi için sonraki ölçümde uygulanacak modeller ve işleyişi 


\section{Albeni, N.}

\section{4. ÖRNEK UYGULAMA}

İşletme 01/01/2016 tarihinde üretimde kullanılmak üzere 100.000TL + \%18 KDV'ye bir makineyi peşin satın alıyor. Makinenin kalıntı değeri sıfır, yararlı ömrü 5 yıl olarak belirlenmekte ve doğrusal amortisman yöntemi uygulanmaktadır. Vergi etkisi gözardı edilmektedir. BOBİ FRS'ye göre muhasebe kayıtları yapılırken Kamu Gözetimi Muhasebe ve Denetim Standartları Kurumunun yayımladığı Finansal Raporlama Standartlarına Uygun Örnek Hesap Planı kullanılmıştır.

Mevcut tekdüzen hesap planında bulunmayıp Kamu Gözetimi Muhasebe ve Denetim Standartları Kurumunun yayımladığı Finansal Raporlama Standartlarına Uygun Örnek Hesap Planında yer alan hesaplar ve açıklamaları aşağıdaki gibidir.

“257 Maddi Duran Varlıklar Değer Düşüklüğü Karşılıkları (-): Bu hesap, maddi duran varlıklara ilişkin değer düşüklüğü karşılıklarının izlenmesinde kullanılır. Hesaplanan karşılık tutarı bu hesaba alacak, kâr veya zarar tablosu hesaplarından maddi duran varlığın kullanım yerine bağlı olarak ilgili fonksiyonel gider hesabına borç kaydedilir. Karşılık ayrılmış olan maddi duran varlıkların elden çıkarılmasında ya da tahmin değişikliklerine bağlı olarak ayrılan değer düşüklüğü zararının kısmen ya da tamamen iptali halinde bu hesaba borç kaydedilir. Değer düşüklüğü zararının iptali işlemi değer düşüklüğü karşılığının ayrıldığı dönemde veya ayrıldığı dönemden sonra olmasına bakılmaksızın karşılık giderinin kayıt edildiği ilgili fonksiyonel gider hesabına alacak kaydedilerek yapılır" (KGK, 2021).

“551 Maddi Duran Varlıklar Yeniden Değerleme Artışları: Bu hesap, işletmenin yeniden değerleme modeli kullanarak ölçtüğü maddi duran varlıkların yeniden değerlenmesinden ortaya çıkan net değer artışlarının izlenmesinde kullanılır. BOBİ FRS'yi uygulayan işletmeler açısından; dönem içerisinde yapılan yeniden değerleme sonucunda maddi duran varlığın değerinde ortaya çıkan değer artışları ilgili maddi duran varlık hesabının borcu karşılığında bu hesaba alacak kaydedilir. Bununla birlikte ortaya çıkan değer artışı, aynı varlığın daha önce kâr veya zararla ilişkilendirilmiş bulunan değer azalışlarını tersine çevirdiği ölçüde bu hesapta muhasebeleştirilmez, maddi duran varlığın kullanım yerine bağlı olarak ilgili fonksiyonel gider hesabının alacağına kaydedilir. Yapılan değerleme sonucunda maddi duran varlığın değerinde ortaya çıkan değer azalışları bu hesapta ilgili varlığa ilişkin yer alan birikimli tutar ölçüsünde, ilgili maddi duran varlık hesabının alacağı karşılığında bu hesaba borç kaydedilir. Bununla birlikte, dönemde ortaya çıkan değer azalışının bu hesapta yer alan birikimli tutarı aşan kısmı bu hesapta muhasebeleştirilmez, maddi duran 
varlığın kullanım yerine bağlı olarak ilgili fonksiyonel gider hesabının borcuna kaydedilir" (KGK, 2021).

“629 Diğer Giderler: Uygulanan geçerli finansal raporlama çerçevesine göre varlıklara ilişkin değer düşüklüğü zararlarının varlığın kullanım yerine bağlı olarak ilgili fonksiyonel gider hesabına kaydedildiği durumlarda, üretim bölümüyle ilgili kullanılan varlıklara ilişkin değer düşüklüğü zararları ya da yeniden değerleme değer azalışları ile bunların iptalleri maliyet hesapları kullanılmadan doğrudan bu hesapta izlenir" (KGK, 2021).

Y1l sonlarında makinenin gerçeğe uygun değerleri aşağıdaki gibidir:

31/12/2017'de 72.000

$31 / 12 / 2018$ 'de 64.800

$31 / 12 / 2019$ 'da 36.720

$31 / 12 / 2020$ 'de 26.622

$\mathrm{Bu}$ bilgilere göre makine ilk kayda maliyet bedeliyle alındıktan sonra, işletmenin uygulayacağı maliyet modeli ve yeniden değerleme modeline göre yapacağı yevmiye kayıtları aşağıdaki gibi olacaktır. İlk yıl her iki modele göre aynı yevmiye kayıtları yapılacaktır.

İlk yıl yapılacak yevmiye kaydı:

1

253 TESİ,, MAKINE VE CIHHAZLAR

191 INNDIRILECEK KDV

100 KASA

Alış kaydı.

2

730 GENEL ÜRETIMM GIDDERLERİ

258 BIRIKKMIS AMORTISMANLAR

İlk yıl amortisman kaydı. $(100.000 * \% 20=20.000)$

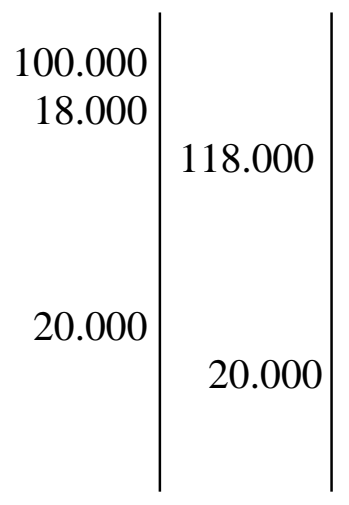

31/12/2016'da aşağıdaki hesapların bakiyeleri gösterildiği gibidir:

253 TESIS, MAKINE VE CIHAZLAR: 100.000

258 BİRIKMIŞ AMORTISMANLAR: 20.000

\subsection{Maliyet Modeline Göre Kayıtlar}

Maliyet modeline göre; "Maddi duran varlıklar, sonraki ölçümlerinde birikmiş amortisman ve varsa birikmiş değer düşüklüğü zararları indirildikten suretiyle maliyeti üzerinden değerlenir" (BOBİ FRS, paragraf 12.15). 


\section{Albeni, N.}

2017 yılı için hesaplamalar ve kayıtlar:

Makinenin net değeri (100.000-20.000)

$=80.000$

Makinenin geri kazanılabilir tutarı

$=72.000$

Makinede ortaya çıkan değer azalışı (düşüklüğü) $(72.000-80.000)=8.000$

Kamu Gözetimi Kurumunun yayımladığı Finansal Raporlama Standartlarına Uygun Örnek Hesap Planına göre yapılacak yevmiye kaydı aşağıdaki gibidir:

3 629 DİĞER GIDERLER 257 MDV DEĞER DÜŞÜK. KRȘL.

Değeri düşen maddi duran varlık (MDV) için karşılık ayrılması.

$4 \longrightarrow$ 31/12/2017

730 GENEL ÜRETIMM GIDERLERİ 258 BİRIKMMIŞ AMORTİSMANLAR

Amortisman kayd.

$100.000 * \% 20=20.000$

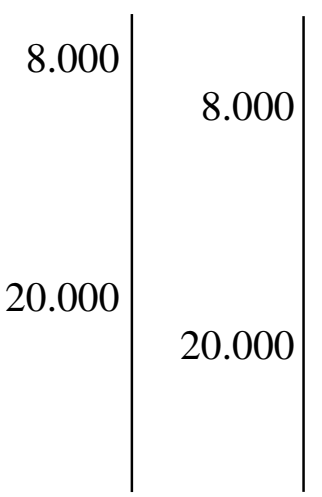

31/12/2017'de aşağıdaki hesapların bakiyeleri gösterildiği gibidir:

$\begin{array}{ll}253 \text { TESIS, MAKINE VE CIHAZLAR } & : \mathbf{1 0 0 . 0 0 0} \\ 258 \text { BİRIKKMIŞ AMORTISMANLAR } & : 20.000+20.00=\mathbf{4 0 . 0 0 0} \\ \text { 629 DİĞER GIDERLER } & : \mathbf{8 . 0 0 0}\end{array}$

257 MDV DEĞER DÜŞÜK. KRŞL.

: 8.000

2018 yılı için hesaplamalar ve kayıtlar:

Makinenin net değeri (100.000-40.000)

$$
=60.000
$$

Makinenin gerçeğe uygun değeri

$=64.800$

Makinede ortaya çıkan değer artışı (64.800-60.000)

$=4.800$

Daha önceki yılda ayrılan karşılık tutarı

$=8.000$

İptal edilmesi gereken karşıllı tutarı

$=4.800$

Kamu Gözetimi Kurumunun yayımladığı Finansal Raporlama Standartlarına Uygun Örnek Hesap Planına göre yapılacak yevmiye kaydı aşağıdaki gibidir:

3. yevmiye kaydı ile ayrılan MDV değer düşüklüğü karşılığının kısmen iptal edilmesi.

$6-31 / 12 / 2018$

730 GENEL ÜRETIMM GIDERLERİ

258 BİRIKMIŞ AMORTİSMANLAR

20.000

Amortisman kayd.

$100.000 * \% 20=20.000$

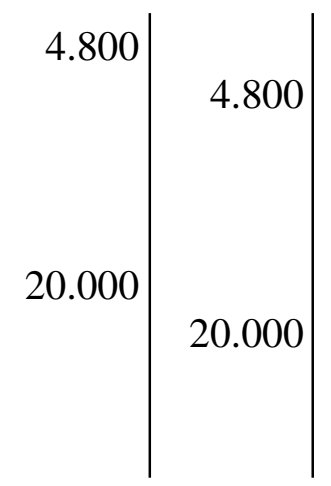


31/12/2018'de aşağıdaki hesapların bakiyeleri gösterildiği gibidir:

\section{TESIS, MAKINE VE CIHAZLAR}

258 BİRIKKMIŞ AMORTISMANLAR

257 MDV DEĞER DÜŞÜK. KRŞL.

629 DİĞER GİDERLER

2019 yılı için hesaplamalar ve kayıtlar:

Makinenin net değeri (100.000-60.000)

Makinenin geri kazanılabilir tutarı

Makinede ortaya çıkan değer azalışı (36.720-40.000)
: 100.000

: $40.000+20.000=\mathbf{6 0 . 0 0 0}$

: $8.000-4.800=\mathbf{3 . 2 0 0}$

: (4.800)

$=40.000$

$=36.720$

$=3.280$

Kamu Gözetimi Kurumunun yayımladığı Finansal Raporlama Standartlarına Uygun Örnek Hesap Planına göre yapılacak yevmiye kaydı aşağıdaki gibidir:

$7 \quad 31 / 12 / 2019$

629 DİĞER GİDERLER

257 MDV DEĞER DÜŞÜK. KRŞL.

Değeri düşen maddi duran varlık (MDV) için

karşılık ayrılması.

$8-31 / 12 / 2019$

730 GENEL ÜRETIMM GIDERLERİ

258 BİRIKKMIŞ AMORTİSMANLAR

Amortisman kayd.

$100.000 * \% 20=20.000$

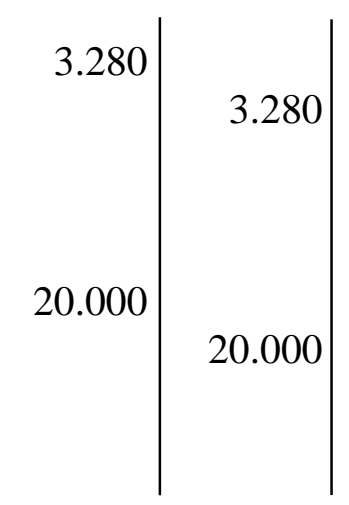

31/12/2019'da aşağıdaki hesapların bakiyeleri gösterildiği gibidir:

253 TESIS, MAKINE VE CIHAZLAR

258 BİRIKMIŞ AMORTİSMANLAR

629 DİĞER GIDERLER

257 MDV DEĞER DÜŞÜK. KRŞL.

2020 yılı için hesaplamalar ve kayıtlar:

Makinenin net değeri (100.000-80.000)

Makinenin gerçeğe uygun değeri

Makinede ortaya çıkan değer artışı (26.622-20.000)

Daha önceki yılda ayrılan karşılık tutarı

İptal edilmesi gereken karşı1lık tutarı
: 100.000

: $60.000+20.00=\mathbf{8 0 . 0 0 0}$

: 3.280

$: 3.200+3.280=\mathbf{6 . 4 8 0}$

$$
\begin{aligned}
& =20.000 \\
& =26.622 \\
& =6.622 \\
& =6.480 \\
& =6.480
\end{aligned}
$$




\section{Albeni, N.}

Kamu Gözetimi Kurumunun yayımladığı Finansal Raporlama Standartlarına Uygun Örnek Hesap Planına göre yapılacak yevmiye kaydı aşağıdaki gibidir: 31/12/2020

257 MDV DEĞER DÜŞÜK. KRŞL. 629 DİĞER GIDERLER

Daha önceden ayrılan MDV değer düşüklüğü karşılığının tamamının iptal edilmesi.

10 $31 / 12 / 2020$

730 GENEL ÜRETIM GIDERLERİ 258 BİRIKMIŞ AMORTISMANLAR

Amortisman kayd1.

$100.000 * \% 20=20.000$

31/12/2020'de aşağıdaki hesapların bakiyeleri gösterildiği gibidir:

253 TESIS, MAKINE VE CIHAZLAR

258 BİRIKMIŞ AMORTİSMANLAR

257 MDV DEĞER DÜŞÜK. KRŞL.

629 DİĞER GİDERLER
: 100.000

: $80.000+20.000=\mathbf{1 0 0 . 0 0 0}$

: $6.480-6.480=\mathbf{0}$

: (6.480)

Kamu Gözetimi Kurumunun yayımladığı Finansal Raporlama Standartlarına Uygun

Örnek Hesap Planına göre yapılacak yevmiye kaydı aşağıdaki gibidir:

$$
11
$$
$31 / 12 / 2020$

258 BİRIKMMIŞ AMORTİSMANLAR 253 TESIS, MAKINNE VE CIHAZLAR

Makine finansal tablo dışı bırakıldığında yapılacak yevmiye kaydı

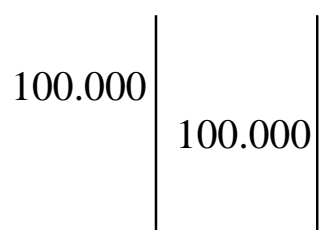

\subsection{Yeniden Değerleme Modeline Göre Değerlendirilmesi}

"İlk kayda almadan sonra bir maddi duran varlık yeniden değerlenmiş tutarı üzerinden ölçüldüğünde ölçüme esas alınacak değer, yeniden değerlemenin yapıldığ1 tarihteki gerçeğe uygun değeridir. Bu tarihten sonra varlığın yeniden değerlenmiş tutarı; varlığın yeniden değerlendiği tarihteki gerçeğe uygun değerinden, yeniden değerlemenin yapıldığı tarihten sonraki birikmiş amortisman tutarı ve birikmiş değer düşüklüğü zararı indirilerek hesaplanır” (BOBİ FRS, paragraf 12.16).

"Bir maddi duran varlık yeniden değerlemeye tabi tutulduğunda varlığın defter değeri yeniden değerlenmiş tutara göre düzeltilirken aşağıda yer verilen yöntemlerden biri kullanılabilir" (KGK, BOBİ FRS Modül 12):

- Brüt Yöntem ya da

- Net Yöntem. 


\subsubsection{Brüt Yönteme Göre Değerleme ve Kayıtlar}

2017 yılı için hesaplamalar aşağıdaki gibidir (Bakınız: Gökgöz ve Temelli, 2016: 149):

Makinenin net değeri (100.000-20.000)

$=80.000$

Makinenin geri kazanılabilir tutarı

$=72.000$

Makinede ortaya çıkan değer azalışı

$=8.000$

Yeniden değerleme azalış oranı (8.000/80.000)

$=\% 10$

Makinenin kayıtlı değerindeki azalış (100.000*010)

$=10.000$

Birikmiş amortismandaki azalış (20.000*\%10)

$=2.000$

Maddi duran varlık yeniden değerleme azalışı

$=8.000$

Kamu Gözetimi Kurumunun yayımladığı Finansal Raporlama Standartlarına Uygun Örnek Hesap Planına göre yapılacak yevmiye kaydı aşağıdaki gibidir:

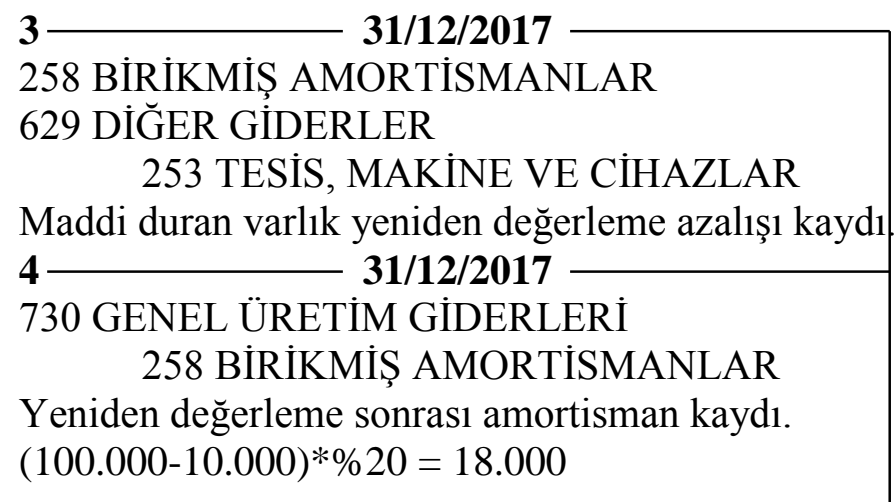

31/12/2017'de aşağıdaki hesapların bakiyeleri gösterildiği gibidir:
253 TESIS, MAKİNE VE CİHAZLAR
: 100.000-10.000=90.000
258 BİRIKMIŞ AMORTISMANLAR
: 20.000-2.000+18.000=36.000
629 DİĞER GIDERLER
: 8.000

2018 yılı için hesaplamalar aşağıdaki gibidir (Bakınız: Gökgöz ve Temelli, 2016):

$\begin{array}{ll}\text { Makinenin net değeri (90.000-36.000) } & =54.000 \\ \text { Makinenin gerçeğe uygun değeri } & =64.800 \\ \text { Makinede ortaya çıkan değer artışı } & =10.800 \\ \text { Yeniden değerleme artış oranı }(10.800 / 54.000) & =\% 20 \\ \text { Makinenin kayıtlı değerindeki artış }(90.000 * \% 20) & =18.000 \\ \text { Birikmiş amortismandaki artış (36.000*\%20) } & =7.200 \\ \text { Maddi duran varlık yeniden değerleme artışı } & =10.800\end{array}$

Daha önceki yılda kâr ya da zarar ile ilişkilendirilmiş bulunan

yeniden değerleme değer azalışı $\quad=8.000$

Yansıtılacak MDV Yeniden değerleme değer artışı = 2.800 
Albeni, N.

Kamu Gözetimi Kurumunun yayımladı̆̆ı Finansal Raporlama Standartlarına Uygun

Örnek Hesap Planına göre yapılacak yevmiye kaydı aşağıdaki gibidir:

5 31/12/2018

253 TESIS, MAKINE VE CIHHAZLAR

258 BIRIIKMISS AMORTISMANLAR

629 DİĞER GİDERLER

551 MDV YENIDEN DEĞERLEME ARTIŞLARI

3. yevmiye kaydında oluşan MDV yeniden değerleme azalışının 629 nolu hesap ile iptal edilip, farkin 551 nolu hesaba kaydedilmesi.

630 GENEL ÜRETIM GIDERLERİ 258 BİRIKMMIŞ AMORTISSMANLAR

Yeniden değerleme sonrası amortisman kaydı. $(90.000+18.000) * \% 20=21.600$

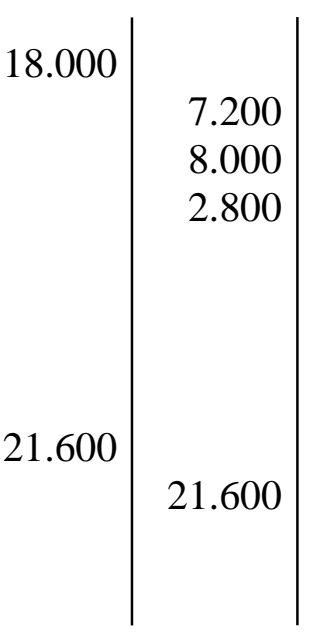

31/12/2018'de aşağıdaki hesapların bakiyeleri gösterildiği gibidir:

\section{TESIS, MAKINNE VE CİHAZLAR}

258 BİRİKMIŞ AMORTİSMANLAR

551 MDV YENIDEN DEĞERLEME ARTIŞLARI

629 DİĞER GIIDERLER

2019 yılı için hesaplamalar aşağıdaki gibidir (Bakınız: Gökgöz ve Temelli, 2016):

Makinenin net değeri (108.000-64.800)

Makinenin geri kazanılabilir tutarı

Makinede ortaya çıkan değer azalışı

Yeniden değerleme azalış oranı (6.480/43.200)

Makinenin kayıtlı değerindeki azalış (108.000*\%15)

Birikmiş amortismandaki azalış (64.800*\%20)

Maddi duran varlık yeniden değerleme azalışı

Daha önceki yılda hesaplanarak diğer kapsamlı gelire

yansıtılan MDV yeniden değerleme artış1

Kâr ya da zarara yansitılacak değerleme farkı
: 90.000+18.000=108.000

: $36.000+7.200+21.600=\mathbf{6 4 . 8 0 0}$

: 2.800

: (8.000)

$=43.200$

$=36.720$

$=6.480$

$=\% 15$

$=16.200$

$=9.720$

$=6.480$

$=2.800$

$=3.680$ 
Kamu Gözetimi Kurumunun yayımladığı Finansal Raporlama Standartlarına Uygun Örnek Hesap Planına göre yapılacak yevmiye kaydı aşağıdaki gibidir:

7

258 BİRIKMMIST AMORTISMANLAR

551 MDV YENIDEN DEĞERLEME ARTIŞLARI

629 DİĞER GIDERLER

253 TESİ, MAKİNE VE CİHAZLAR

Ortaya çıkan yeniden değerleme azalışının, ilk önce 5. yevmiye

kaydında 551 nolu hesabın bakiyesi kadarlık kısmının

indirilmesi, fazla k1smin 629 nolu hesaba kaydedilmesi.

8

31/12/2019

730 GENEL ÜRETIMM GIDERLERİ

258 BIRIKKMISS AMORTISSMANLAR

Yeniden değerleme sonrası amortisman kaydı.

$(108.000-16.200) * \% 20=18.360$

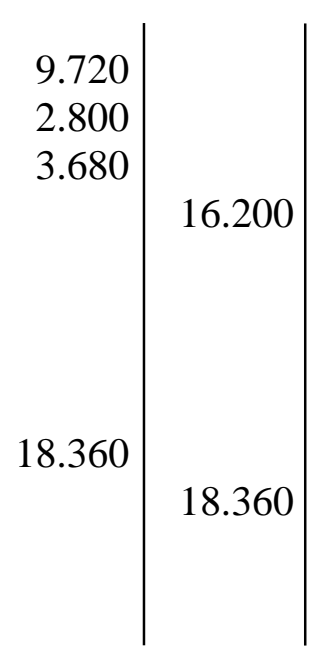

31/12/2019'da aşağıdaki hesapların bakiyeleri gösterildiği gibidir:

\section{TESIS, MAKINE VE CIHAZLAR}

258 BİRIKMIŞ AMORTİSMANLAR

629 DİĞER GİDERLER
: 108.000-16.200=91.800

: $64.800-9.720+18.360=\mathbf{7 3 . 4 4 0}$

: 3.680

2020 yılı için hesaplamalar aşağıdaki gibidir (Bakınız: Gökgöz ve Temelli, 2016):

Makinenin net değeri (91.800-73.440)

$$
=18.360
$$

Makinenin gerçeğe uygun değeri

$=26.622$

Makinede ortaya çıkan değer artışı

$=8.262$

Yeniden değerleme artış oranı $(8.262 / 18.360)$

$=\% 45$

Makinenin kayıtlı değerindeki artış $(91.800 * 045)=41.310$

Birikmiş amortismandaki artış (73.440*045) $=33.048$

Maddi duran varlık yeniden değerleme artışı $\quad=8.262$

Daha önceki yılda kâr ya da zarar ile ilişkilendirilmiş bulunan

yeniden değerleme değer azalışı

$=3.680$

Yansitılacak MDV Yeniden değerleme değer artış1 = 4.582 
Albeni, N.

Kamu Gözetimi Kurumunun yayımladı̆̆ı Finansal Raporlama Standartlarına Uygun Örnek Hesap Planına göre yapılacak yevmiye kaydı aşağıdaki gibidir:

9 $31 / 12 / 2020$

253 TESIS, MAKINNE VE CIHHAZLAR

258 BIRIIKMISS AMORTISMANLAR

629 DİĞER GİDERLER

551 MDV YENIDEN DEĞERLEME ARTIŞLARI

7. yevmiye kaydında oluşan MDV yeniden değerleme azalışının 629 nolu hesabın alacağı ile mahsup edilip, fazla kısmın 551 nolu hesaba kaydedilmesi.

$\mathbf{1 0} \mathbf{3 1 / 1 2 / 2 0 2 0}$
730 GENEL ÜRETIMM GIDERLERİ
258 BİRIKMIŞ AMORTISMANLAR
Yeniden değerleme sonras1 amortisman kayd.
$(91.800+41.310)^{* \% 20}=26.622$

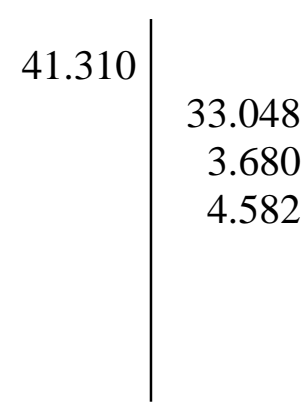

31/12/2020'de makine finansal tablo dışı bırakılmadan önce aşağıdaki hesapların bakiyeleri gösterildiği gibidir:

253 TESIS, MAKINE VE CIHAZLAR

258 BİRIKMIŞ AMORTİSMANLAR

551 MDV YENIDEN DEĞERLEME ARTIŞLARI

629 DİĞER GIDERLER
: $91.800+41.310=\mathbf{1 3 3 . 1 1 0}$

: $73.440+33.048+26.622=\mathbf{1 3 3 . 1 1 0}$

: 4.582

: (3.680)

"Bir maddi duran varlık finansal tablo dışı bırakıldığında bu varlığa ilişkin olarak yeniden değerleme yedeğinde yer alan birikmiş tutar "Geçmiş Yıllar Kârları/Zararları" kalemine aktarılır" (BOBİ FRS, paragraf 12.20).

12

258 BİRIKMİŞ AMORTISMANLAR

551 MDV YENIDEN DEĞERLEME ARTIŞLARI

253 TESİS, MAKINE VE CIHHAZLAR

570 GEÇMISŞ YILLAR KARLARI

Makine finansal tablo dışı bırakıldığında amortisman ve

varlık hesaplarının kapanışı, 551 nolu hesabın 570 nolu hesaba devri kaydi.

\subsubsection{Net Yönteme Göre Değerleme ve Kayıtlar}

2017 yılı için hesaplamalar ve kayıtlar:

Makinenin net değeri (100.000-20.000)

$=80.000$

Makinenin geri kazanılabilir tutarı

$=72.000$

Makinede ortaya çıkan değer azalışı

$=8.000$

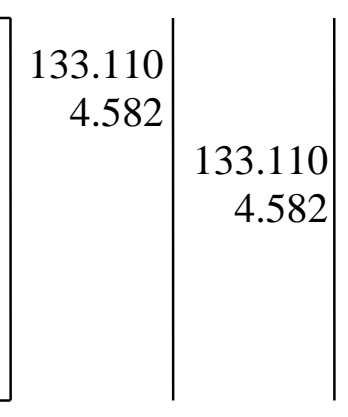


3

258 BİRIKKMIŞ AMORTİSMANLAR 253 TESIS, MAKINNE VE CIHAZLAR

Birikmiş Amortismanın iptali.

$4-31 / 12 / 2017$

629 DİĞER GIDERLER

253 TESIS, MAKİNE VE CİHAZLAR

Maddi duran varlık yeniden değerleme azalışı kaydı

5

730 GENEL ÜRETIM GIDERLERİ

258 BIRİKMIS AMORTISMANLAR

Yeniden değerleme sonrası amortisman kaydı.

$(100.000-20.000-8.000) / 4=18.000$

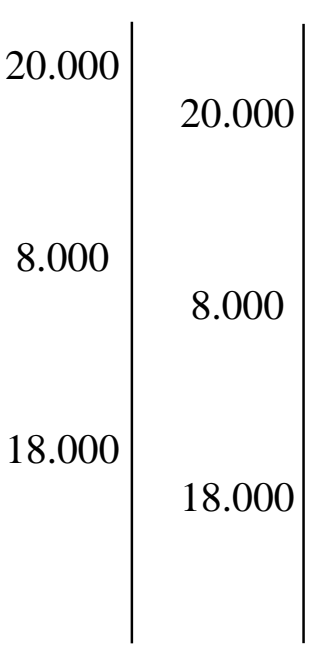

31/12/2017'de aşağıdaki hesapların bakiyeleri gösterildiği gibidir:

\section{TESIS, MAKİNE VE CİHAZLAR}

258 BİRIKKMIŞ AMORTİSMANLAR

629 DİĞER GIDERLER

2018 yılı için hesaplamalar ve kayıtlar:

Makinenin net değeri (72.000-18.000)

Makinenin gerçeğe uygun değeri

Makinede ortaya çıkan değer artışı
: 100.000-20.000-8.000=72.000

: 20.000-20.000+18.000=18.000

: 8.000

$$
\begin{aligned}
& =54.000 \\
& =64.800 \\
& =10.800
\end{aligned}
$$

Daha önceki yılda kâr ya da zarar ile ilişkilendirilmiş bulunan

yeniden değerleme değer azalışı $\quad=8.000$

Yansitılacak MDV Yeniden değerleme değer artışı $=2.800$

$6-31 / 12 / 2018$

258 BİRİKMISŞ AMORTISMANLAR 253 TESIS, MAKINNE VE CIHHAZLAR

Birikmiş Amortismanın iptali.

\section{7}

253 TESIS, MAKİNE VE CIHHAZLAR

31/12/2018

629 DİĞER GIDERLER

551 MDV YENIDEN DEĞERLEME ARTIŞLARI

4. yevmiye kaydında oluşan MDV yeniden değerleme azalışının 629 nolu hesap ile iptal edilip, fazla kısmın 551 nolu hesaba kaydedilmesi.

$\mathbf{8} 30$ GENEL ÜRETIM GIDERLERİ 258 BİRIKKMIŞ AMORTİSMANLAR

Yeniden değerleme sonrası amortisman kaydı. $(72.000-18.000+10.800) / 3=21.600$ 
Albeni, N.

31/12/2018'de aşağıdaki hesapların bakiyeleri gösterildiği gibidir:

253 TESIS, MAKINE VE CIHAZLAR

258 BİRIKMIŞ AMORTİSMANLAR

551 MDV YENIDEN DEĞERLEME ARTIŞLARI

629 DİĞER GIDERLER

2019 yılı için hesaplamalar ve kayıtlar:

Makinenin net değeri (64.800-21.600)

Makinenin geri kazanılabilir tutarı

Makinede ortaya çıkan değer azalışı

Daha önceki yılda hesaplanarak diğer kapsamlı gelire

yansıtılan MDV yeniden değerleme artış1

Kâr ya da zarara yansıtılacak değerleme fark1
: $72.000-18.000+10.800=\mathbf{6 4 . 8 0 0}$

: $18.000-18.000+21.600=\mathbf{2 1 . 6 0 0}$

: 2.800

: (8.000)

$$
=43.200
$$$$
=36.720
$$$$
=6.480
$$

$=2.800$

$=3.680$

\section{9} 31/12/2019

258 BİRIKMMIŞ AMORTİSMANLAR 253 TESIS, MAKINE VE CIHAZLAR

Birikmiş Amortismanın iptali.

$10-31 / 12 / 2019$

$551 \mathrm{MDV}$ YENIDEN DEĞERLEME ARTIŞLARI

629 DİĞER GIDERLER

253 TESIS, MAKINNE VE CİHAZLAR

Ortaya çıkan yeniden değerleme azalışının, ilk önce 7. yevmiye kaydında 551 nolu hesabın bakiyesi kadarlık kısmının indirilmesi, fazla k1smin 629 nolu hesaba kaydedilmesi.

11 31/12/2019

730 GENEL ÜRETIM GIDERLERİ 258 BİRIKKMIS AMORTİSMANLAR

Yeniden değerleme sonrası amortisman kaydı. $(64.800-21.600-6.480) / 2=18.360$

31/12/2019'da aşağıdaki hesapların bakiyeleri gösterildiği gibidir:

253 TESIS, MAKINE VE CIHAZLAR

258 BİRİKMIŞ AMORTİSMANLAR 629 DİĞER GİDERLER
: 64.800-21.600-6.480=36.720

: 21.600-21.600+18.360=18.360

: 3.680 
2020 yılı için hesaplamalar ve kayıtlar:

Makinenin net değeri (36.720-18.360)

$$
\begin{aligned}
& =18.360 \\
& =26.622 \\
& =8.262
\end{aligned}
$$

Makinenin gerçeğe uygun değeri

Makinede ortaya çıkan değer artışı

Daha önceki yılda kâr ya da zarar ile ilişkilendirilmiş bulunan

yeniden değerleme değer azalışı $\quad=3.680$

Yansitılacak MDV Yeniden değerleme değer artış1 = 4.582

$12 \longrightarrow 31 / 12 / 2020$

258 BİRIKKMIŞ AMORTISSMANLAR

253 TESİS, MAKINNE VE CIHHAZLAR

Birikmiş Amortismanın iptali.

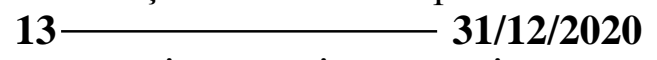

253 TESIS, MAKINE VE CIHAZLAR

629 DİĞER GIDERLER

551 MDV YENIDEN DEĞERLEME ARTIŞLARI

10. yevmiye kaydında oluşan MDV yeniden değerleme azalışının 629 nolu hesabın alacağı ile mahsup edilip, fazla kısmın 551 nolu hesaba kaydedilmesi.

\begin{tabular}{l}
$\mathbf{1 4} \mathbf{3 1 / 1 2 / 2 0 2 0}$ \\
730 GENEL ÜRETIM GIDERLERİ \\
258 BİRIKMIȘ AMORTISMANLAR \\
Yeniden değerleme sonrası amortisman kaydı. \\
$(36.720-18.360+8.260) / 1=26.620$ \\
\hline
\end{tabular}

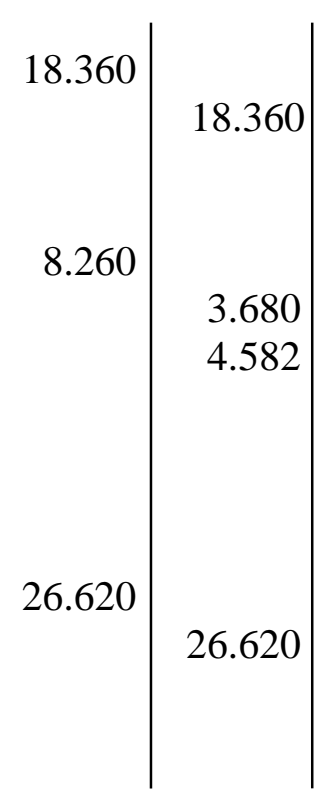

31/12/2020'de makine finansal tablo dışı bırakılmadan önce aşağıdaki hesapların bakiyeleri gösterildiği gibidir:

253 TESİS, MAKINE VE CIHAZLAR

258 BİRIKMIŞ AMORTİSMANLAR

551 MDV YENIDEN DEĞERLEME ARTIŞLARI

629 DİĞER GIDERLER
: $36.720-18.360+8.260=\mathbf{2 6 . 6 2 0}$

: $18.360-18.360+26.620=\mathbf{2 6 . 6 2 0}$

: 4.582

: (3.680)

\section{5} 31/12/2020

258 BİRIKMISŞ AMORTISMANLAR

551 MDV YENIDEN DEĞERLEME ARTIŞLARI

253 TESIS, MAKINE VE CIHAZLAR

570 GEÇMISŞ YILLAR KARLARI

Makine finansal tablo dışı bırakıldığında amortisman ve varlık hesaplarının kapanışı, 551 nolu hesabın 570 nolu hesaba devri kaydi.

Makine varlık olarak muhasebeleştirildikten sonra işletme maliyet modeli ya da yeniden değerleme modelini kullanmayı seçtiğinde oluşacak farklılıklar aşağıdaki tabloda gösterilmeye çalışılmıştır. 
Albeni, N.

Tablo 1. Varlık olarak muhasebeleştirildikten sonra makinenin işletme tarafindan seçilecek maliyet modeli ya da yeniden değerleme modeline göre değerlenmesi

\begin{tabular}{|c|c|c|c|c|c|c|c|c|c|c|}
\hline \multicolumn{11}{|c|}{ MALIYET MODELI } \\
\hline Yillar & $\begin{array}{c}(1) \\
\text { (GUD) }\end{array}$ & 253 & 258 & $\begin{array}{c}(2) \\
(253-258) \\
\end{array}$ & \begin{tabular}{|c|}
$\begin{array}{c}\text { Değer Artışı } \\
(1-2)\end{array}$ \\
\end{tabular} & $\begin{array}{c}\text { Değer } \\
\text { Düşüklüğüu } \\
\text { (Azalışı) } \\
(1-2)\end{array}$ & $\begin{array}{c}629 \\
\text { Borç } \\
\end{array}$ & $\begin{array}{c}629 \\
\text { Alacak } \\
\end{array}$ & 257 & $\begin{array}{c}257 \\
\text { Bakiye }\end{array}$ \\
\hline 2017 & 72.000 & 100.000 & 20.000 & 80.000 & & 8.000 & 8.000 & & 8.000 & 8.000 \\
\hline 2018 & 64.800 & 100.000 & 40.000 & 60.000 & 4.800 & & & 4.800 & -4.800 & 3.200 \\
\hline 2019 & 36.720 & 100.000 & 60.000 & 40.000 & & 3.280 & 3.280 & & 3.280 & 6.480 \\
\hline 2020 & 26.622 & 100.000 & 80.000 & 20.000 & 6.622 & & & 6.480 & -6.480 & 0 \\
\hline \multicolumn{11}{|c|}{ YENIDEN DEĞERLEME MODELİ (BRÜT YÖNTEM) } \\
\hline Yillar & $\begin{array}{c}(\mathbf{1}) \\
\text { (GUD) }\end{array}$ & 253 & 258 & $\begin{array}{c}(2) \\
(253-258) \\
\end{array}$ & \begin{tabular}{|c|} 
Değer Artışı \\
$(1-2)$
\end{tabular} & $\begin{array}{c}\text { Değer Azalışıı } \\
(1-2)\end{array}$ & $\begin{array}{c}629 \\
\text { Borç } \\
\end{array}$ & $\begin{array}{c}629 \\
\text { Alacak }\end{array}$ & 551 & $\begin{array}{c}551 \\
\text { Bakiye }\end{array}$ \\
\hline 2017 & 72.000 & 100.000 & 20.000 & 80.000 & & 8.000 & 8.000 & & & \\
\hline 2018 & 64.800 & 90.000 & 36.000 & 54.000 & 10.800 & & & 8.000 & 2.800 & 2.800 \\
\hline 2019 & 36.720 & 108.000 & 64.800 & 43.200 & & 6.480 & 3.680 & & -2.800 & \\
\hline 2020 & 26.622 & 91.800 & 73.440 & 18.360 & 8.262 & & & 3.680 & 4.582 & 4.582 \\
\hline \multicolumn{11}{|c|}{ YENIDEN DEĞERLEME MODELI (NET YÖNTEM) } \\
\hline Yillar & $\begin{array}{c}\text { (1) } \\
\text { (GUD) }\end{array}$ & 253 & 258 & $\begin{array}{c}(2) \\
(253-258) \\
\end{array}$ & $\begin{array}{c}\text { Değer Artışı } \\
(1-2)\end{array}$ & $\begin{array}{c}\text { Değer Azalışı } \\
(1-2)\end{array}$ & $\begin{array}{c}629 \\
\text { Borç }\end{array}$ & $\begin{array}{c}629 \\
\text { Alacak } \\
\end{array}$ & 551 & $\begin{array}{c}551 \\
\text { Bakiye }\end{array}$ \\
\hline 2017 & 72.000 & 100.000 & 20.000 & 80.000 & & 8.000 & 8.000 & & & \\
\hline 2018 & 64.800 & 72.000 & 18.000 & 54.000 & 10.800 & & & 8.000 & 2.800 & 2.800 \\
\hline 2019 & 36.720 & 64.800 & 21.600 & 43.200 & & 6.480 & 3.680 & & -2.800 & \\
\hline 2020 & 26.622 & 36.720 & 18.360 & 18.360 & 8.262 & & & 3.680 & 4.582 & 4.582 \\
\hline
\end{tabular}

Her iki modele göre 2017 yılında 8.000TL'lik değer azalışı (değer düşüklüğü) meydana gelmiştir. Maliyet modeline göre 8.000TL'lik değer düşüklüğü için karşılık ayrılmış, 257 nolu karşılık hesabının alacağı karşılığında 629 nolu hesabın borcuna kayıt yapılmıştır. Yeniden değerleme modeline göre ise karşılık ayrılmamış, 253 nolu hesabın alacağı karşıllığında 629 nolu hesabın borcuna kayıt yapılmıştır.

2018 yılında maliyet modeline göre 4.800TL'lik değer artışı oluşmuş ve bu değer artış1 629 nolu hesabın alacağına kayıt yapılarak 2017 yılında 8.000TL ayrılan karşılık miktarının 4.800TL'lik kısmı iptal edilmiştir. Yeniden değerleme modeline göre aynı yı1 10.800TL'lik değer artışı oluşmuş ve 629 nolu hesabın alacağına kayıt yapılarak bir önceki yıl 629 nolu hesabın borcuna yazılan 8.000TL'lik değer azalışı iptal edilmiş, kalan 2.800TL'lik fazla kısım ise 551 nolu hesaba kaydedilmiştir.

2019 yılında maliyet modeline göre 3.280TL'lik değer düşüklüğü meydana gelmiş ve 257 nolu karşılık hesabının alacağı karşılığında 629 nolu hesabın borcuna kayıt yapılmıştır. Yeniden değerleme modeline göre ise aynı yıl 6.480TL'lik değer azalışı meydana gelmiş, ilk önce bir önceki yıl 551 nolu hesaba yazılan 2.800TL'lik kısım 551 nolu hesabın borcuna 
yazılarak mahsup edilmiş, 6.480-2.800=3.680TL'lik fazla kısım ise 629 nolu hesabın borcuna kaydedilmiştir.

2020 yılında maliyet modeline göre 6.622TL'lik değer artışı meydana gelmiş ve 629 nolu hesabın alacağına 6.480TL kaydedilerek, 257 nolu karşılık hesabının bakiyesinde yer alan 6.480TL'lik kısım mahsup edilmiş, 6.622-6.480=142TL'lik fazla kısım içinse hiçbir kayıt yapılmamıştır. Yeniden değerleme modeline göre ise aynı yıl 8.262TL'lik değer artışı meydana gelmiş, bir önceki yıl 629 nolu hesabın borcuna kaydedilen 3.680TL'lik kısım 629 nolu hesabın alacağına yazılarak iptal edilmiş, kalan 8.262-3.680=4.582TL ise 551 nolu hesabın alacağına kaydedilmiştir. Makine finansal tablo dışı kaldığında ise maliyet modeline göre 257 nolu hesap bakiye vermediğinden sadece 253 nolu hesap 258 nolu hesapla kapatılmıştır. Yeniden değerleme modeline göre ise 551 nolu hesapta bulunan 4.582TL'lik bakiye 570 nolu hesaba aktarılarak, 253 nolu hesap da 257 nolu hesap ile kapatılmıştır. Modeller karşılaştırıldığında 2020 yılında maliyet modeline göre 257 nolu karşılık hesabında bakiye bulunmamakta dolayısıyla 570 nolu hesaba kayıt yapılamamakta, yeniden değerleme modeline göre ise 551 nolu hesapta 4.582TL'lik bakiye bulunmakta ve bu 570 nolu hesaba aktarilarak kapatılmaktadır. Bu farkın sebebi ise maliyet modeli ile yeniden değerleme modelinde 20172020 yılları boyunca 253-258 nolu hesaplar arasındaki farklılıkların toplamı ile maliyet yönteminde 2020 yılında 6.622-6.480=142TL'lik değer artışının kayda alınmamasından kaynaklanmaktadır. Yeniden değerleme modelinde hem brüt yöntem hem de net yöntem kullanılmakta ve her iki yönteme göre de aynı sonuç ortaya çıkmaktadır.

Makine varlık olarak muhasebeleştirildikten sonra işletme maliyet modeli ya da yeniden değerleme modelini kullanmayı seçtiğinde yıllara göre hesapların bakiyeleri aşağıdaki tabloda gösterilmektedir. 
Albeni, N.

Tablo 2. Makinenin değerlenmesinde kullanılan maliyet modeli ve yeniden değerleme modeline göre hesapların bakiyeleri

\begin{tabular}{|c|c|c|c|c|}
\hline \multirow{3}{*}{ Yillar } & \multirow[b]{3}{*}{ Hesaplar } & \multicolumn{3}{|c|}{ Bakiyeler } \\
\hline & & \multirow[b]{2}{*}{ Maliyet Yöntem } & \multicolumn{2}{|c|}{ Yeniden Değerleme Modeli } \\
\hline & & & Brüt Yöntem & Net Yöntem \\
\hline \multirow{2}{*}{2016} & 253 & 100.000 & 100.000 & 100.000 \\
\hline & 258 & 20.000 & 20.000 & 20.000 \\
\hline \multirow{4}{*}{2017} & 253 & 100.000 & 90.000 & 72.000 \\
\hline & 258 & 40.000 & 36.000 & 18.000 \\
\hline & 629 & 8.000 & 8.000 & 8.000 \\
\hline & 257 & 8.000 & & \\
\hline \multirow{5}{*}{2018} & 253 & 100.000 & 108.000 & 64.800 \\
\hline & 258 & 60.000 & 64.800 & 21.600 \\
\hline & 257 & 3.200 & & \\
\hline & 629 & -4.800 & -8.000 & -8.000 \\
\hline & 551 & & 2.800 & 2.800 \\
\hline \multirow{5}{*}{2019} & 253 & 100.000 & 91.800 & 36.720 \\
\hline & 258 & 80.000 & 73.440 & 18.360 \\
\hline & 629 & 3.280 & 3.680 & 3.680 \\
\hline & 257 & 6.480 & & \\
\hline & 551 & & & \\
\hline \multirow{5}{*}{2020} & 253 & 100.000 & 133.110 & 26.620 \\
\hline & 258 & 100.000 & 133.110 & 26.620 \\
\hline & 257 & 0 & & \\
\hline & 629 & -6.480 & -3.680 & -3.680 \\
\hline & 551 & & 4.582 & 4.582 \\
\hline \multirow{5}{*}{$\begin{array}{c}\text { Finansal Tablo } \\
\text { Dışı Sonrası }\end{array}$} & 253 & 0 & 0 & 0 \\
\hline & 258 & 0 & 0 & 0 \\
\hline & 257 & 0 & & \\
\hline & 551 & & 0 & 0 \\
\hline & 570 & & 4.582 & 4.582 \\
\hline
\end{tabular}

Maliyet modeli ve yeniden değerleme modeli karşılaştırıldığında, maliyet modeline göre 257 nolu karşılık hesabı kullanılırken 551 nolu hesap kullanılmamakta, yeniden değerleme modeline göre ise 551 nolu hesap kullanılırken 257 nolu karşılık hesabı kullanılmamaktadır. Maliyet modeline göre 2020 yılında makine finansal tablo dışı bırakılmadan önce 257 nolu karşılık hesabı bakiye vermemektedir. Yeniden değerleme modelinde ise 2020 y1lında makine finansal tablo dışı bırakılmadan önce hem brüt yöntem hem de net yönteme göre 551 nolu hesap 4.582TL bakiye vermektedir. Makine finansal tablo dışı bırakıldığında maliyet modeline göre 253 nolu hesap 258 nolu hesapla kapatılırken 257 nolu hesap 570 nolu hesaba aktarılarak kapatılmakta fakat 257 nolu hesap bakiye vermediği için 570 nolu hesaba kayıt yapılmamıştır. 
Yeniden değerleme modeline göre ise 253 nolu hesap 258 nolu hesapla kapatılırken 551 nolu hesaptaki 4.582TL'lik bakiye de 570 nolu hesaba aktarılarak kapatılmaktadır.

Maliyet modeline göre değer azalışı olduğunda karşılık ayrılırken, değer artışı olduğunda daha önceden değer düşüklüğü ile ilgili karşılık ayrılmadığıysa ya da daha önceden karşılık ayrıldı ve değer artışı meydana geldiğinde ayrılan karşılık tutarını aşan değer artışı tutarı söz konusuysa bu fazla kısım için bir kayıt yapılmamaktadır. Bu sebeple 2020 yılındaki karşılığın iptali sonrası oluşan 142TL'lik değer artışı fazlası ile ilgili de bir kayıt yapılmamıştır. Her iki modele göre karşılaştırma yaptığımızda 570'e aktarılan 4.582TL'lik farkın 2017-2020 yılları arası 253-258 arasındaki farklılıkların toplamı ile 2020 yılında maliyet modeline göre 142TL'nin kayıtlara alınmamasından kaynaklanmaktadır.

\section{SONUÇ}

BOBİ FRS Bölüm 12'ye göre maddi duran varlıklar ilk kayda alınırken maliyet bedeli ile ölçüm sağlanırken, sonrasında maliyet modeli ya da yeniden değerleme modeli tercih edilir. Bir maddi duran varlık kalemi yeniden değerlemeye tabi tutulduğunda, varlığın defter değeri yeniden değerlenmiş tutara göre düzeltilirken ya brüt yöntem ya da net yöntem kullanılır.

Bir maddi duran varlık için sonraki ölçümde maliyet modeli seçildiyse ve değer düşüklüğü zararı söz konusuysa bu zarar için karşılık ayrılır, eğer değer artışı söz konusuysa bu artış için hiçbir işlem yapılmaz. Eğer karşılık ayrıldıktan sonra değer artışı söz konusuysa önce ayrılan karşılık iptal edilir, fazla kısım içinse hiçbir işlem yapılmaz.

Eğer maddi duran varlık için sonraki ölçümde yeniden değerleme modeli seçildiyse varlığın defter değerini düzeltmek için ya brüt yöntem ya da net yöntem kullanılır. Yeniden değerlemede eğer ilk defa değer artışı meydana gelmişse bu artış Finansal Durum Tablosunda özkaynaklarda yeniden değerleme yedeği kaleminde gösterilmeli, eğer ilk defa değer azalış1 meydana gelmişse Kâr veya Zarar Tablosunda ilgili varlığın kullanıldığı işletme fonksiyonuna ilişkin giderlerin yansıtıldığı kalemde kâr veya zarara yansıtılır.

Eğer daha önceden değer azalışı meydana geldiyse ve sonraki dönem değer artışı söz konusuysa önce daha önce meydana gelen değer azalışı kadarlık kısmı ilgili varlığın kullanıldığı işletme fonksiyonuna ilişkin gider hesabı ile mahsup edilir, fazla kısım varsa özkaynaklarda yeniden değerleme yedeği kaleminde gösterilir.

Eğer daha önceden değer artışı meydana geldiyse ve sonraki dönem değer azalışı söz konusuysa, önce yeniden değerleme yedeği kaleminin bakiyesi kadarlık kısmı mahsup edilir, fazla kısım varsa ilgili varlığın kullanıldığı işletme fonksiyonuna ilişkin gider hesabına kaydedilir. 
Albeni, N.

Bir maddi duran varlık finansal tablo dışı bırakıldığında bu varlığa ilişkin olarak yeniden değerleme yedeğinde yer alan tutar Geçmiş Yı1lar Kârları/Zararları kalemine aktarılır.

BOBİ FRS Bölüm 12'ye göre maddi duran varlıklar için amortisman ayrılması zorunluluktur. Amortisman işlemine varlık yönetim tarafından amaçlanan kullanıma hazır hale geldiği tarihten itibaren başlanır ve varlık finansal tablo dışı bırakıldığında son verilir.

Örnek uygulamada, üretimde kullanılan bir makinenin varlık olarak muhasebeleştirildikten sonra işletme tarafından yapılması gereken yevmiye kayıtları maliyet modeli ve yeniden değerleme modeline göre, yeniden değerleme modeli de hem brüt yönteme hem de net yönteme göre gösterilmeye çalışmıştır. Yevmiye kayıtları yapılırken Kamu Gözetimi Muhasebe ve Denetim Standartları Kurumunun yayımladığı Finansal Raporlama Standartlarına Uygun Örnek Hesap Planı kullanılmıştır. Son olarak yöntemler karşılaştırmalı olarak tabloda gösterilmiş, aradaki farklılıklar belirlenmiş ve farklılıkların sebebi açıklanmaya çalışılmıştır.

Türkiye Muhasebe Standartlarının önemi giderek artmakta olup standartlara uygun muhasebe kayıtlarının yapılabilmesi için Kamu Gözetimi Muhasebe ve Denetim Standartları Kurumunun yayımladığı Finansal Raporlama Standartlarına Uygun Örnek Hesap Planının kullanılması gerektiği düşünülmektedir.

\section{KAYNAKÇA}

Ataman, B., \& Cavlak, H. (2017). Büyük ve orta boy işletmeler için finansal raporlama standardı (BOBİ FRS) ile tam set türkiye muhasebe ve türkiye finansal raporlama standartlarının (TMS/TFRS) karşıllaştırılması. Finans Ekonomi ve Sosyal Araştırmalar Dergisi, 2 (3), 153-168.

Çanakçıŏlu, M. (2018). BOBİ FRS, tam set TFRS ve vergi usul kanunu çerçevesinde maddi duran varlıkların ölçümü. Akademik Sosyal Araştırmalar Dergisi, 6 (80), 349-366.

Durmuş, C. N., \& Kutlu, O. (2020). Büyük ve orta boy işletmeleri için finansal raporlama standardının (BOBİ FRS), Türkiye Muhasebe Standartları (TMS) ve Türkiye Finansal Raporlama Standartları (TFRS) ile karşılaştırılması. Mali Çözüm Dergisi, 30(158), 189-211.

Gökgöz, A., \& Temelli, F. (2016). Taşıyıcı bitkilerin türkiye muhasebe standartları çerçevesinde muhasebeleştirilmesi. Journal of Accounting, Finance and Auditing Studies, 2(4), 142-154.

Güleç, Ö. F. (2018). Maddi ve maddi olmayan duran varlıkların BOBİ FRS ve TFRS açısından değerlendirilmesi. İşletme Araştırmaları Dergisi, 10(4), 904-921.

Kamu Gözetimi Kurumu. BOBİ FRS modül 12 maddi duran varlıklar. https://www.kgk.gov.tr/Portalv2Uploads/files/Duyurular/v2/BOB\%C4\%B0_FRS/Mod\%C3\% BCl\%2012-.pdf / E.T: 15.08.2021.

Kamu Gözetimi Kurumu (2021). Büyük ve orta boy işletmeler için finansal raporlama standardı (2021 Sürümü) https://www.kgk.gov.tr/DynamicContentDetail/10265/Bu\%CC\%88yu\%CC\%88k-ve-OrtaBoy-I\%CC\%87s\%CC\%A7letmeler-I\%CC\%87c\%CC\%A7in-Finansal-Raporlama- 
Standard\%C4\%B1-(BOBI\%CC\%87-FRS)-2021-Su\%CC\%88ru\%CC\%88mu\%CC\%88 / E.T: 10.08.2021.

Kamu Gözetimi Kurumu (2021). Finansal raporlama standartlarına uygun örnek hesap planı, https://www.kgk.gov.tr/Portalv2Uploads/files/Duyurular/v2/TMS/Hesap_Plani_Taslagi_Goru sler_Sonrasi_21_07.pdf / E.T:28.07.2021.

Lazol, İ. (2020). Genel muhasebe. Ekin Yayınevi.

Tuncez, H. A. (2020). TMS 16 ve BOBİ FRS kapsamında maddi duran varlıkların karşılaştırılması. Muhasebe ve Maliye Dergisi, 3(2), 92-109.

Yelgen, E., \& Uyar, S. (2018). BOBİ FRS açısından maddi duran varlıkların muhasebeleştirilmesi. Muhasebe ve Vergi Uygulamaları Dergisi, Özel Sayı, 98-109.

Yücel, S., Öncü, M. A., \& Akaytay, A. (2018). Türkiye'deki güncel muhasebe mevzuatlarına göre maddi duran varlıkların değerleme hükümlerinin karşılaştırması. Van Yüzüncü Yıl Üniversitesi Sosyal Bilimler Enstitüsü Dergisi, 39, 283-304. 